\title{
PRODUCTIVE QUALITY AND DIGESTIBILITY OF NUTRITIVE SUBSTANCES IN THE ORGANISM OF BUNCHES AT THE USE OF FIRE POW
}

\author{
Savchuk Ivan ${ }^{1 *}$, Stepanenko Valentina ${ }^{2}$, Pavliuk Nadiia ${ }^{2}$ \\ ${ }^{1}$ Institute of Agriculture Polesie National Academy of Agrarian Sciences of Ukraine, Zhitomir, Ukraine \\ ${ }^{2}$ Zhytomyr National Agroecological University, Zhitomir, Ukraine
}

\section{ПРОДУКТИВНЫЕ КАЧЕСТВА И ПЕРЕВАРИМОСТЬ ПИТАТЕЛЬНЫХ ВЕЩЕСТВ В ОРГАНИЗМЕ БЫЧКОВ ПРИ ИСПОЛЬЗОВАНИИ ПЕЛЮШКИ}

\author{
Савчук Иван, Степаненко Валентина, Павлюк Надежда \\ Received 11. 5. 2017 \\ Revised 22. 5. 2017 \\ Published 29. 11. 2017
}

The results of scientific research on the solution of the problem of protein supply to young cattle for growing and fattening in the Polesie of Ukraine at the expense of local high-protein feed - peliushki (pea of the field) are summarized. Scientific and production experiments were conducted on the bulls of Ukrainian black-and-white dairy breed in the physiological court of the Institute of Agriculture of Polesye of the National Academy of Sciences of Ukraine. In two experiments, rations for experimental steers of control and experimental groups were the same for energy supply, protein, mineral substances and vitamins. The animals of the control groups received feeds in which the lack of digestible protein was provided by feeding the sunflower meal $(0.64-0.97 \mathrm{~kg} / \mathrm{head} / \mathrm{day})$. In the experimental groups, for the balancing of the rations of feeding young cattle for protein, the grain of peas of the field (natural) $(0.85 \mathrm{~kg} / \mathrm{head} /$ day $)$ and extruded $(1.03 \mathrm{~kg} / \mathrm{head} /$ day $)$ was used. The data of the conducted research experiments indicate that the introduction of different high protein feeds into rations of bulls to ensure the optimal level of digestible protein positively affects the productive qualities of animals. Optimization of rations of feeding of bull-calves on digestible protein due to natural and extruded grain of pea field in comparison with sunflower meal helps to increase daily average weight gain of animals by $2.4-6.8 \%$ and decrease in feed costs per unit of growth by $0.4-4.4 \%$. The inclusion of peas in the field of the ration of young cattle in comparison with sunflower meal promotes better digestibility of crude protein by $2.8 \%$ and lack of extractives by $2.9 \%$. The deposition of nitrogen in the body of the bull-calves of the experimental group relative to the received food and digested was, respectively, 0.8 and $2.3 \%$, than in the control.

Keywords: gobies; pea of the field; sunflower meal; digestible protein; live weight; average daily weight gain Digestibility

\section{Введение}

Протеиновое обеспечение кормовой единицы в зоне Полесья Украины за последние годы не превышает 80 - 82 г. При этом валовой дефицит протеина составляет 18 - 20 \% к потребности. Вследствие этого ежегодные перерасходы кормов при производстве животноводческой продукции исчисляются в десятках тысяч тонн кормовых единиц. Несбалансированность

*Corresponding author: Ivan Savchuk, Institute of Agriculture Polesie National Academy of Agrarian Sciences of Ukraine, Zhitomir, Ukraine, $\triangle$ stepanenko_64@list.ru 
протеинового питания приводит к перерасходу кормов при производстве говядины в 1,65 раза по сравнению с полноценным кормлением (Богданов, 1986; Снітинський та ін., 2004). Поэтому поиск путей решения проблемы белка за счет изыскания новых источников высококачественного протеина и повышения питательной ценности традиционных кормов является актуальным.

Практика зарубежных развитых стран и лучших хозяйств Украины показывает, что проблему кормового белка лучше всего преодолевают за счет бобовых культур, которые накапливают протеина значительно больше, чем другие растения (Зубець та ін., 2010). Вместе с тем, в последние годы в полесских областях Украины начали массово выращивать пелюшку горох полевой. Питательность 1 кг зерна пелюшки составляет 1,16 - 1,24 кормовых единиц с содержанием 194 - 207 г переваримого протеина (Савченко та ін., 2007).

Поэтому целью наших исследований было сравнительное изучение эффективности использования пелюшки (в натуральном и экструдированном виде) со жмыхом подсолнечным (завезенным в зону Полесья) при производстве говядины.

\section{Материалы и методы}

Научно-производственные опыты проведены на бычках украинской черно-пестрой молочной породы на физиологическом дворе Института сельского хозяйства Полесья НААН Украины. Группы подопытных животных формировались по методу пар-аналогов с учетом возраста, живой массы, интенсивности роста (Овсянніков, 1976). Исследования проведены в условиях стойлового периода при привязном содержании животных по следующей схеме (табл. 1).

Таблица 1 Схема научно-производственных опытов

Table 1 Scheme of scientific and industrial experiments

\begin{tabular}{|c|c|c|c|}
\hline $\begin{array}{l}\text { Группы } \\
\text { животных }\end{array}$ & $\begin{array}{l}\text { К-во голов } \\
\text { в группе }\end{array}$ & $\begin{array}{c}\text { Особенности кормления } \\
\text { животных в опытном } \\
\text { периоде }\end{array}$ & $\begin{array}{c}\text { Доля переваримого } \\
\text { протеина в рационе за счет } \\
\text { высокопротеиновых кормов, \% }\end{array}$ \\
\hline $\begin{array}{l}\text { Контрольная } \\
(1 \times)\end{array}$ & 7 & $\begin{array}{c}\text { ОР (3x) (грубые, сочные, } \\
\text { концентрированные и минеральные } \\
\text { корма) + жмых подсолнечный }\end{array}$ & 22,3 \\
\hline Опытная (1х) & 7 & ОР + дерть пелюшки натуральной & 26,0 \\
\hline $\begin{array}{l}\text { Контрольная } \\
(2 \times)\end{array}$ & 6 & $\begin{array}{c}\text { ОРххх (грубые, сочные, } \\
\text { концентрированные и минеральные } \\
\text { корма) + жмых подсолнечный }\end{array}$ & 24,9 \\
\hline Опытная (2xx) & 6 & $\begin{array}{c}\text { ОР + дерть пелюшки } \\
\text { экструдированной }\end{array}$ & 25,1 \\
\hline
\end{tabular}

№ опыта: 1× - длительность опытного периода 92 дня; 2× - длительность опытного периода 122 дня; $3 \times$ ОР - основной рацион.

В двух опытах рационы для подопытных бычков контрольных и опытных групп были одинаковыми по набору кормов, энергетической питательности, обеспеченности протеином, минеральными веществами и витаминами.

Животные контрольных групп получали корма рационов, в которых недостаток до нормы переваримого протеина обеспечивали за счет скармливания жмыха подсолнечного (0,64 - 0,97 кг/гол/сутки). Для балансирования рационов кормления молодняка крупного рогатого скота по протеину в опытных группах использовали пелюшку натуральную (0,85 кг/гол/сутки) и экструдированную (1,03 кг/гол/сутки). 


\section{Результаты и их обсуждение}

Данные проведенных научно-исследовательских экспериментов свидетельствуют о том, что ввод в кормовые рационы бычков разных высокобелковых кормов для обеспечения оптимального уровня переваримого протеина положительно влияет на продуктивные качества животных (табл. 2).

Таблица 2 Показатели продуктивности подопытных бычков

Table 2 The productivity of the experimental steers

\begin{tabular}{|c|c|c|c|c|c|c|c|}
\hline \multirow{3}{*}{ 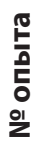 } & \multirow{3}{*}{$\begin{array}{l}\text { Группы } \\
\text { бычков }\end{array}$} & \multicolumn{3}{|c|}{ Среднесуточные привесы, г } & \multicolumn{3}{|c|}{ Затраты кормов на 1 кг привеса, корм. ед. } \\
\hline & & \multirow{2}{*}{$M \pm m$} & \multicolumn{2}{|c|}{ 土 к контролю } & \multirow{2}{*}{$\mathbf{M}$} & \multicolumn{2}{|c|}{ 士 к контролю } \\
\hline & & & $\mathbf{r}$ & $\%$ & & $\mathbf{r}$ & $\%$ \\
\hline \multirow[t]{2}{*}{1} & контрольная & $862 \pm 63$ & - & - & 7,91 & - & - \\
\hline & опытная & $883 \pm 47$ & +21 & $+2,4$ & 7,88 & $-0,03$ & $-0,4$ \\
\hline \multirow[t]{2}{*}{2} & контрольная & $938 \pm 29$ & - & - & 8,67 & - & - \\
\hline & опытная & $1002 \pm 36$ & +64 & $+6,8$ & 8,29 & $-0,38$ & $-4,4$ \\
\hline
\end{tabular}

При скармливании контрольным бычкам жмыха подсолнечного, а животным опытной группы - дерти пелюшки натуральной в первом опыте существенной разницы в привесах живой массы не установлено (862 - 883 г) при практически одинаковых затратах кормов на 1 кг привеса (7,88 - 7,91 корм. ед.).

Использование в рационах растущего молодняка крупного рогатого скота дерти экструдированной пелюшки (опыт 2) способствовало получению более высоких среднесуточных привесов живой массы (на 64 г, или 6,8 \%) по сравнению с аналогичными показателями контрольных животных, которым давали жмых подсолнечный. Затраты кормов на 1 кг привеса живой массы бычков контрольной группы были больше на 0,38 кормовых единиц, или на 4,6 \% относительно аналогов опытной группы.

Результаты убойных качеств животных свидетельствуют о том, что достоверной разницы в показателях убойного выхода, выхода мяса и его энергетической ценности с трехреберного отруба в зависимости от белкового корма в рационе не установлено. Однако, незначительно больше оказался выход мяса и его калорийность у молодняка контрольной группы.

Переваримость кормов - это второй этап после потребления и очень важный при оценке эффективности использования тех или иных новых кормов, которые внедряются в производстве для кормления животных. Исходя из этого, в первом опыте, где изучали использование жмыха подсолнечного и дерти натуральной пелюшки, был проведен балансовый опыт по переваримости питательных веществ и балансу азота.

Анализ результатов обменного опыта показал, что переваримость питательных веществ исследуемых кормов рационов бычками обеих групп была на достаточно высоком уровне (табл. 3). 
Таблица 3 Переваримость питательных веществ кормов рационов подопытными животными, $\%(n=3 ; M \pm m)$

Table 3 Nutrient digestibility of feed rations in experimental animals, $\%(n=3 ; M \pm m)$

\begin{tabular}{|l|c|c|}
\hline \multirow{2}{*}{ Питательные вещества } & \multicolumn{2}{|c|}{ Группы } \\
\cline { 2 - 3 } & контрольная & опытная \\
\hline Сухое вещество & $57,9 \pm 1,4$ & $57,7 \pm 1,1$ \\
\hline Органическое вещество & $60,4 \pm 1,3$ & $60,0 \pm 0,9$ \\
\hline Сырой протеин & $61,9 \pm 2,5$ & $64,7 \pm 1,7$ \\
\hline Сырой жир & $68,5 \pm 4,5$ & $68,0 \pm 8,7$ \\
\hline Сырая клетчатка & $50,9 \pm 1,0$ & $47,8 \pm 1,9$ \\
\hline БЭВ & $64,9 \pm 1,6$ & $67,8 \pm 2,5$ \\
\hline
\end{tabular}

Использование натуральной пелюшки в качестве высокобелкового корма к рациону молодняка крупного рогатого скота на откорме сравнительно со жмыхом подсолнечным способствовало лучшей переваримости сырого протеина (на 2,8 \%) и БЭВ (на 2,9 \%) при недостоверной разнице $(P<0,95)$. Несколько хуже переваривали сырую клетчатку (на 3,1\%, $P<0,95)$ бычки опытной группы, нежели их аналоги из контрольной, при почти одинаковых показателях сухого (57,7 - 57,9 \%) и органического веществ $(60,0$ - 60,4 \%) и сырого жира $(68,0-68,5 \%)$.

Данные изучения баланса азота в организме подопытных животных свидетельствуют об отсутствии каких-либо существенных различий между бычками контрольной и опытной групп (табл. 4).

Таблица 4 Среднесуточный баланс азота у подопытных животных, г

Table 4 The average daily nitrogen balance in experimental animals, $g$

\begin{tabular}{|l|c|c|}
\hline \multirow{2}{*}{ Показатели } & \multicolumn{2}{|c|}{ Группы } \\
\cline { 2 - 3 } & контрольная & опытная \\
\hline Принято с кормами & 187,71 & 180,45 \\
\hline Выделено с калом & $63,96 \pm 3,45$ & $63,33 \pm 2,81$ \\
\hline Переварено & 123,75 & 117,12 \\
\hline Выделено с мочой & $37,68 \pm 2,87$ & $32,89 \pm 1,71$ \\
\hline Всего выделено & 101,64 & 96,22 \\
\hline Отложено в теле: г & $86,07 \pm 1,88$ & $84,23 \pm 3,09$ \\
\hline \% к принятому & 45,9 & 46,7 \\
\hline \% к переваренному & 69,6 & 71,9 \\
\hline
\end{tabular}

Баланс азота у молодняка крупного рогатого скота обеих групп был положительным. Однако животные опытной группы сравнительно с контрольными аналогами несколько меньше откладывали азота в теле - на 2,1% (84,23 против 86,07 г). Но если сравнивать относительные показатели эффективности использования азота, так в теле бычков опытной группы его 
отложилось больше относительно к принятому и переваренному, соответственно, на 0,8 и 2,3 \%, нежели в контрольной группе.

Таким образом, потребление молодняком крупного рогатого скота гороха полевого оказало положительное влияние на переваримость питательных веществ в их организме и усвоение азота.

\section{Выводы}

Оптимизация рационов кормления бычков на откорме по переваримому протеину (согласно существующих норм) за счет натурального и экструдированного зерна гороха полевого сравнительно со жмыхом подсолнечным способствует повышению среднесуточных привесов живой массы животных на 2,4 - 6,8 \% и снижению затрат кормов на единицу прироста на 0,4-4,4\%. Включениепелюшки в качестве высокобелкового корма в состав рациона молодняка крупного рогатого скота сравнительно со жмыхом подсолнечным способствует лучшей переваримости сырого протеина на 2,8 и БЭВ на 2,9\%. Отложение азота в теле бычков опытной группы относительно к принятому и переваренному было больше, соответственно, на 0,8 и $2,3 \%$, чем в контроле.

\section{Литература}

Богданов, Г.О., Каравашенко, В.Ф., Зверев, А.Л. та ін. 1986. Довідник по годівлі сільськогосподарських тварин. Вид.-во Урожай. 488 с.

Снітинський, В.В., Яремко, Р.М., Кружель, Б.Б. 2004. Протеїнове живлення молодняку великої рогатої худоби. Вісник аграрної науки, № 12, с. 25-29.

Зубець, М.В. та ін. 2010. Наукові основи агропромислового виробництва в зоні Полісся і західному регіоні України. Київ: Изд-во Аграрна наука. 944 с. ISBN 978-966-540-292-3.

Савченко, Ю. та ін. 2007. Зерно пелюшки: його кормова ефективність. Тваринництво України, № 5, с. 37-39. ISBN 0321-1525.

Овсянников, А.И. 1979. Основы опытного дела в животноводстве. Москва: Изд-во Колос. 304 с. 